Original Article

\title{
Antiadhesion and antibiofilm potential of Fagonia indica from Cholistan desert against clinical multidrug resistant bacteria
}

\author{
Potencial de antiadesão e antibiofilme de Fagonia indica do deserto do Cholistão contra \\ bactérias multirresistentes clínicas
}

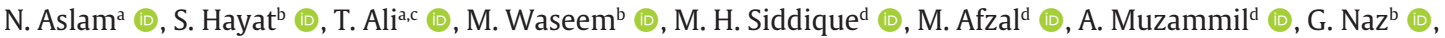 \\ A. Sarwarb (i) and S. Muzammilb* (B) \\ ${ }^{a}$ Government College University, Department of Biochemistry, Faisalabad, Pakistan \\ ${ }^{\mathrm{b} G o v e r n m e n t ~ C o l l e g e ~ U n i v e r s i t y, ~ D e p a r t m e n t ~ o f ~ M i c r o b i o l o g y, ~ F a i s a l a b a d, ~ P a k i s t a n ~}$ \\ 'University of Agriculture, Department of Biochemistry, Faisalabad, Pakistan \\ dGovernment College University, Department of Bioinformatics and Biotechnology, Faisalabad, Pakistan
}

\begin{abstract}
High resistance to antimicrobials is associated with biofilm formation responsible for infectious microbes to withstand severe conditions. Therefore, new alternatives are necessary as biofilm inhibitors to control infections. In this study, the antimicrobial and antibiofilm activities of Fagonia indica extracts were evaluated against MDR clinical isolates. The extract exhibited its antibiofilm effect by altering adherence and disintegration of bacterial cell wall. Fagonia indica has antibacterial effect as minimum inhibitory concentration (MIC) values ranging from 125 to $500 \mu \mathrm{g} \mathrm{mL} \mathrm{m}^{-1}$ and minimum bactericidal concentration (MBC) value was $500-3000 \mu \mathrm{g} \mathrm{mL}^{-1}$ against multidrug resistant (MDR) clinical isolates. The extract exhibited its antibiofilm effect by altering adherence and disintegration of bacterial cell wall. Fagonia indica had antibacterial effect as minimum inhibitory concentration (MIC) values ranging from 125 to $500 \mu \mathrm{g} \mathrm{mL}-1$ and minimum bactericidal concentration (MBC) value was $500-3000 \mu \mathrm{gL}^{-1}$ against MDR isolates. The maximum inhibitory effects of Fagonia indica chloroform extract on biofilm formation was observed on Staphylococcus aureus (71.84\%) followed by Klebsiella pneumoniae (70.83\%) after 48 hrs showing that inhibition is also time dependent. Our results about bacterial cell protein leakage indicated that MDR isolates treated with chloroform extract of Fagonia indica showed maximum protein leakage of K. pneumoniae (59.14 $\mu \mathrm{g}$

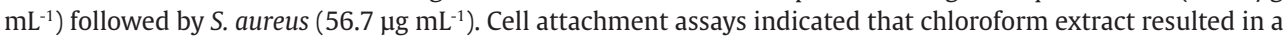
43.5-53.5\% inhibition of cell adherence to a polystyrene surface. Our results revealed that extracts of Fagonia indica significantly inhibited biofilm formation among MDR clinical isolates, therefore, could be applied as antimicrobial agents and cost effective biofilm inhibitor against these MDR isolates.
\end{abstract}

Keywords: biofilm inhibitors, biofilm formation, MDR, antibacterial activity.

\begin{abstract}
Resumo
A alta resistência aos antimicrobianos está associada à formação de biofilme responsável por micróbios infecciosos para suportar condições severas. Portanto, novas alternativas são necessárias como inibidores de biofilme para controlar infecções. Neste estudo, as atividades antimicrobiana e antibiofilme dos extratos de Fagonia indica foram avaliadas contra isolados clínicos MDR. 0 extrato exibiu seu efeito antibiofilme ao alterar a aderência e a desintegração da parede celular bacteriana. Fagonia indica tem efeito antibacteriano com valores de concentração inibitória mínima (CIM) variando de 125 a $500 \mu \mathrm{g} \mathrm{mL}-1$, e valor de concentração bactericida mínima (MBC) de 500 $3000 \mu \mathrm{g} \mathrm{mL}-1$ contra isolados clínicos multirresistentes (MDR). 0 extrato exibiu seu efeito antibiofilme ao alterar a aderência e a desintegração da parede celular bacteriana. Fagonia indica teve efeito antibacteriano com valores de concentração inibitória mínima (CIM) variando de 125 a $500 \mu \mathrm{g} \mathrm{mL}-1$, e concentração bactericida mínima (MBC) de 500-3000 $\mu \mathrm{g} \mathrm{mL}-1$ contra isolados MDR. Os efeitos inibitórios máximos do extrato de clorofórmio Fagonia indica na formação de biofilme foi observada em Staphylococcus aureus (71,84\%), seguido por Klebsiella pneumoniae (70,83\%) após 48 horas, mostrando que a inibição também é dependente do tempo. Nossos resultados sobre extravasamento de proteínas de células bacterianas indicaram que isolados MDR tratados com extrato clorofórmico de Fagonia indica apresentaram vazamento máximo de proteínas de K. pneumoniae $(59,14 \mu \mathrm{g} \mathrm{mL}-1)$, seguido por S. aureus $(56,7 \mu \mathrm{g} \mathrm{mL}-1)$. Ensaios de fixação de células indicaram que o extrato de clorofórmio resultou em uma inibição de 43,5-53,5\% da aderência das células a uma superfície de poliestireno. Nossos resultados revelaram que extratos de Fagonia indica inibiram significativamente a formação de biofilme entre isolados clínicos MDR, portanto, poderiam ser aplicados como agentes antimicrobianos e inibidores de biofilme de baixo custo contra esses isolados MDR.
\end{abstract}

Palavras-chave: inibidores de biofilme, formação de biofilme, MDR, atividade antibacteriana.

*e-mail: saimamuzammil83@gmail.com

Received: June 23, 2020 - Accepted: November 5, 2020

This is an Open Access article distributed under the terms of the Creative Commons Attribution License, which permits unrestricted use, distribution, and reproduction in any medium, provided the original work is properly cited. 


\section{Introduction}

Human infections especially due to the microorganisms are a significant cause of morbidity and mortality in tropical and subtropical countries (Pontes et al., 2019). However, in recent years, over-reliance on antibiotics to cope with infections lead to the emergence of resistance among these pathogens. Multidrug resistant (MDR) bacteria have become a serious threat for public health (Vaibhav et al., 2014) as effectiveness of currently used antibiotics is questionable towards these pathogenic bacteria. Thus, discovery of novel antimicrobials and other alternative ways is of paramount importance. In past, a vast number of native medicinal plants have been used to treat infectious diseases (Mostafa et al., 2018).

Pakistan is one of the richest countries in medicinal flora. Cholistan desert scovered the 2.6 million hectares of Pakistan and the soil of Cholistan desert has been classified as saline or saline-sodic (Arshad et al., 2006). Due to the extreme weather conditions and humidity variations, mostly xerophytic species are present in the Cholistan desert (Akhter and Arshad, 2006) from one of which is Zygophyllaceae family that mostly contains shrubs and herbs (Mnafgui et al., 2012). Fagonia indica belongs to this family that has other related species including Fagonia cretica; Fagonia arabica Linn (Daniel 2016). Fagonia indica present in sub-tropical and hot temperature regions like Morocco, Tunisia, Algeria, Cyprus, Saudi Arabia and the dry regions of the salty rocks of India and western Pakistan (Ali et al., 2008). Fagonia indica mostly used in the Indo-Pak for the treatment of fever, urinary discharges, asthma, liver troubles, tumors and peptic ulcer disease (PUD) (Marwat and Khan, 2012; Mahdy et al., 2018). Antimicrobial activity of Fagonia indica has been reported against different microbes like Salmonella typhi,, Escherichia coli and Staphylococcus epidermidis (Marwat and Khan, 2012; Mahdy et al., 2018).

Keeping in view, the threat of multidrug resistant (MDR) bacteria, present study has been designed to investigate the in vitro antibacterial activity of different extracts of Fagonia indica prepared by different extraction methods against MDR bacteria. Effect of Fagonia indicaon biofilm formation and adhesion was also evaluated in our study.

\section{Materials and Methods}

\subsection{Plant collection and extracts preparation}

Fagonia indica plant was collected randomLy from Tehsil Yazman, Cholistan district, Bahawalpur Punjab, Pakistan and was identified from the Department of Botany, Government College University, Faisalabad under voucher no 244-bot-19. After the identification, the collected plants were rinsed with distilled water and finally dried in shade. Dried material i.e., root and aerial parts were ground in a mixer grinder into fine powder separately. Powdered material (50 grams) of each plant part was sequentially extracted by soxhlet apparatus using different solvents
$(500 \mathrm{~mL})$ in increasing polarity (ethyl acetate, chloroform, ethanol and methanol) and then filtered. The filtrate was concentrated by evaporating the solvent using a rotary evaporator (Heidolph, Germany) under reduced pressure $40^{\circ} \mathrm{C}$ (Kumar et al., 2012). Extracts were weighed and their percentage extraction yields were calculated using the following Formula 1:

$$
\text { Extract yield } \%=\mathrm{R} / \mathrm{S} \times 100\left(\begin{array}{l}
\text { where } \mathrm{R} ; \\
\text { weight of extracted plant residues and } \mathrm{S} ; \\
\text { weight of plant raw sample }
\end{array}\right) \text { (1) }
$$

Plant extract was completely dried dissolved in dimethyl sulfoxide (DMSO, 0.1\%) and then further diluted using LB broth to get required concentrations.

\subsection{Bacterial strains}

The antibacterial activity of plant extracts was evaluated against four MDR clinical isolates procured from Department of Microbiology, Government College University Faisalabad, Pakistan i.e. Staphylococcus aureus, Pseudomonas aeruginosa, Escherichia coli and Klebsiella pneumoniae.

\subsection{Inoculum preparation}

Each bacterial strain was sub-cultured in Lauria Bertani (LB) broth at $37^{\circ} \mathrm{C}$. The growth of bacteria was harvested using $10 \mathrm{~mL}$ of normal saline and this suspension was adjusted to 0.5 McFarland as described by Canli et al. (2016).

\subsection{Antibacterial activity determination}

Antibacterial activity of different plant extracts was determined using the agar-well diffusion method. Briefly, $100 \mu \mathrm{L}$ of fresh bacterial culture (absorbance adjusted to 0.5 McFarland) was uniformLy spread onto LB agar plates. The plates were allowed to dry at room temperature for 30 minutes and then wells of $5 \mathrm{~mm}$ (in diameter) were made. After that, $100 \mu \mathrm{L}$ of each extract was dispensed into the wells at concentrations of 1000 , 500, 250 and $125 \mu \mathrm{g} \mathrm{mL} \mathrm{m}^{-1}$. DMSO (0.1\%) was used as a negative control. Plates were incubated at $37^{\circ} \mathrm{C}$ for 18-24 hours. Antibacterial activity was detected by measuring the diameter of inhibitory zone around each well (Sánchez et al., 2016).

\subsection{MIC and MBC determination}

The MIC (minimum inhibitory concentration) and MBC (minimum bactericidal concentration) of plant extracts was determined by broth microdilution method as suggested by Giner et al. (2012) with minor alterations. Two fold serial dilutions of each plant extract were made (0-1000 $\left.\mu \mathrm{g} \mathrm{mL}^{-1}\right)$ in LB broth using 96-wells microtiter plate. $10 \mu \mathrm{L}$ of bacterial inoculum with turbidity adjusted to 0.5 McFarland was dispensed into the wells containing different concentrations of plant extracts and incubated at $37^{\circ} \mathrm{C}$ for 24 hours. Following incubation, bacterial cell viability was detected by a change in color from yellow to blue after addition of methanolic solution of 3-[4,5-dimethylthiazol-2-yl]-2,5-diphenyltetrazolium 
bromide (MTT; $5 \mathrm{mg} / \mathrm{mL}$ ). The lowest concentration at which there was no change in the color of redox dye was considered, as MIC against the target bacteria. Each experiment was performed in triplicates including positive and negative controls.

To determine $\mathrm{MBC}, 100 \mu \mathrm{L}$ from each well exhibiting no visible growth was re inoculated on LB agar plates and the plates were incubated at $37^{\circ} \mathrm{C}$ for 24 hours. MBC was defined as the lowest concentration of plant extract exhibiting no bacterial growth. DMSO (0.1\%) was used as negative control and ampicillin was used as positive control.

\subsection{Detection of cellular protein leakage}

In order to detect the disintegration of cell envelope after the treatment of cells with plant extract exhibiting the lowest MIC, cellular protein leakage was measured. For this purpose, a bacterial inoculum at a final density of $0.5 \mathrm{McF}$ arland was added to LB medium having various concentrations $(0.5 \times$ MIC and $1 \times$ MIC respective to each target bacteria) of Fagonia indica extract. Cells grown in LB medium without plant extract were used as control. Each tube was placed on shaking incubator at $37{ }^{\circ} \mathrm{C}$ for 24 hours. After incubation, $1 \mathrm{~mL}$ from each culture tube was harvested by centrifugation $\left(300 \times \mathrm{g}, 4^{\circ} \mathrm{C}\right)$ for 20 minutes and supernatant was collected that was further used for the quantification of protein using Bradford assay. The absorbance of the suspension was measured at $595 \mathrm{~nm}$ (Politou and Temussi, 2015).

\subsection{Cell attachment assay}

To determine the effect of plant extract on adhesion of bacteria to polystyrene surfaces, method described by Raut et al. (2013) was used. Briefly, $100 \mu l$ of plant extract at sub-inhibitory concentration dissolved in DMSO and further diluted into LB broth was dispensed to the wells of 96-wells microtiter plate. A bacterial inoculum at a final density of 0.5 McFarland was diluted with fresh LB broth (1:20), then $100 \mu \mathrm{l}$ of this inoculum was added to the wells of a 96- wells microtiter plate followed by incubation at $37^{\circ} \mathrm{C}$ for 12 hours. After incubation, the non-adhered cells were removed by washing thrice with $0.85 \% \mathrm{NaCl}$. Cells adhered to the wells of polystyrene surface of microtiter plate were stained with $0.1 \%$ crystal violet for 10 minutes followed by elution with $200 \mu \mathrm{l}$ of $33 \%$ glacial acetic acid. Measuring absorbance at $546 \mathrm{~nm}$ did the quantification of number of cells adhering to the wells. Negative and positive controls were also included in each experiment.

\subsection{Biofilm formation assay}

To assess the effect of plant extracts on biofilm formation of target bacteria, method proposed by Stepanović et al. (2000) was used with minor alterations. Briefly, $100 \mu l$ of plant extract at sub-inhibitory concentration dissolved in DMSO and further diluted into LB broth was dispensed to the wells of 96-wells microtiter plate. A bacterial inoculum at a final density of $0.5 \mathrm{McFarland}$ was diluted with fresh LB broth (1:20), then $100 \mu$ of this inoculum was added to the wells of a 96- wells microtiter plate followed by incubation at $37^{\circ} \mathrm{C}$ for 24 and 48 hours. Following incubation, medium was removed from each well and the wells were washed thrice with normal saline $(0.85 \%$ $\mathrm{NaCl}$ ) and the biofilms formed were stained by $0.1 \%$ crystal violet for 10 minutes. After staining, the excessive dye was removed by washing thrice with normal saline, whereas, bound cells were eluted by the addition of $200 \mu \mathrm{l}$ of $33 \%$ glacial acetic acid. Finally the absorbance of the eluted suspension was measured at $546 \mathrm{~nm}$.

\subsection{Statistical analysis}

All the experiments were performed in triplicates and the results were presented as mean and standard error (SE). For statistical analysis, Student's t-test and ANOVA (Analysis of Variance) using Microsoft, Excel was performed. A value of $P<0.05$ was considered as significant value.

\section{Results}

The data of percentage yield of extracts of Fagonia indica prepared by using different solvents has been presented in Table 1 . As indicated, \%age extractive yield was found to be in the range of $4.12-6.27 \%$. The highest yield was found for chloroform extract of Fagonia made from roots followed by methanolic extract obtained from aerial parts.

The effect of various extracts on MDR bacteria was determined by agar well diffusion assay using different concentrations of each extract. Our results revealed that Fagonia extracts exhibited antibacterial activity in a dose dependent manner since increasing the concentrations of extracts increased the diameter of zone of inhibition (Table 1). Diameter of zones of inhibition ranged between 5-15 mm and the largest zone of inhibition was observed against $S$. aureus using chloroform extract (concentration used was $1000 \mu \mathrm{g} \mathrm{mL}^{-1}$ ) of plant made from aerial parts. The results also indicated that extracts made from aerial part of Fagonia indica were more effective against tested bacteria as compared to the extracts made from roots (Table 1).

To find out the antibacterial susceptibility of multi-drug resistant bacteria against different extracts of Fagonia indica, MIC and MBC was evaluated by broth microdilution method. The results indicated that MIC values ranged between $125-1000 \mu \mathrm{g} \mathrm{mL}^{-1} \mathrm{l}$ and the least value was observed for chloroform extract made from aerial parts against S. aureus and $P$. aeruginosa (Table 2). Our data also displayed that MBC values ranged between 500-4000 $\mu \mathrm{g}$ $\mathrm{mL}^{-1}$ and the presented values were $2-8$ times greater than their respective MIC value (Table 3 ).

In order to determine whether plant extract of Fagonia resulted in the disintegration of cellular membrane, the most active extract was selected (based on MIC values) and the leakage of protein was detected by Bradford method. The results have indicated that those bacterial cells treated with chloroform extract (aerial part) of Fagonia 
Table 1. Antibacterial effects of Fagonia indica extracts determined by Agar well diffusion method.

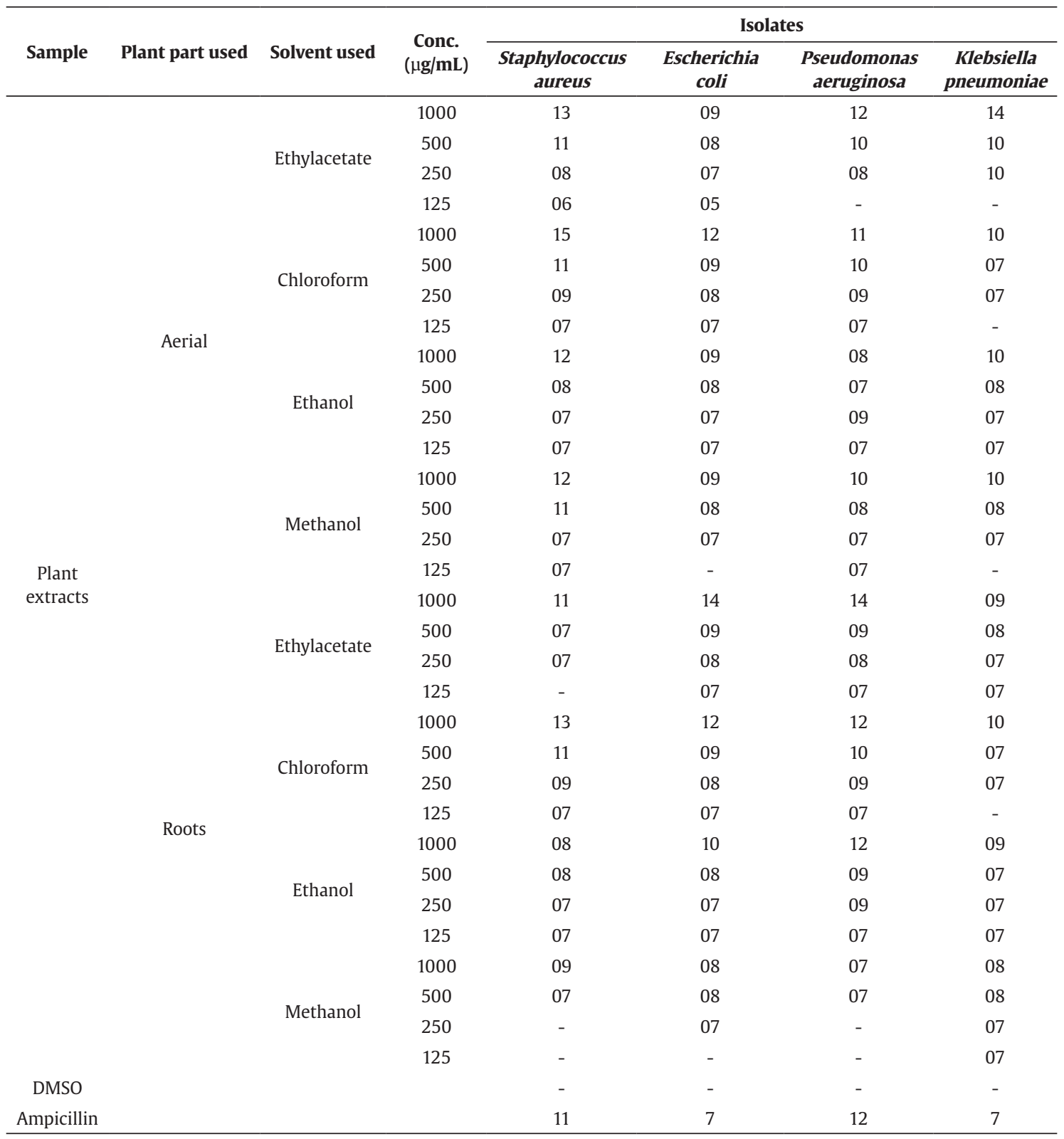

Table 2. Minimum inhibitory concentrations (MICs in $\mu \mathrm{g} / \mathrm{mL}$ ) of Fagonia indica extracts against MDR bacteria.

\begin{tabular}{cccccc}
\hline \multirow{2}{*}{ Extracts used } & Plant part used & \multicolumn{3}{c}{ Isolates } \\
\cline { 3 - 6 } & & $\begin{array}{c}\text { Staphylococcus } \\
\text { aureus }\end{array}$ & Escherichia coli & $\begin{array}{c}\text { Pseudomonas } \\
\text { aeruginosa }\end{array}$ & $\begin{array}{c}\text { Klebsiella } \\
\text { pneumoniae }\end{array}$ \\
\hline Ethylacetate & 250 & 500 & 500 & 250 \\
Chloroform & Aerial & 125 & 250 & 125 & 250 \\
Ethanol & & 250 & 250 & 500 & 500 \\
Methanol & & 250 & 250 & 250 & 250 \\
Ethylacetate & \multirow{250}{*}{ Roots } & 250 & 500 & 500 & 500 \\
Chloroform & & 500 & 500 & 500 \\
Ethanol & & 250 & 500 & 500 & 500 \\
Methanol & & & & 250 & 250 \\
\hline
\end{tabular}


Table 3. Minimum bactericidal concentrations (MBCs in $\mu \mathrm{g} / \mathrm{mL}$ ) of Fagonia indica extracts against MDR bacteria.

\begin{tabular}{|c|c|c|c|c|c|}
\hline \multirow[b]{2}{*}{ Extracts used } & \multirow[b]{2}{*}{ Plant part used } & \multicolumn{4}{|c|}{ Isolates } \\
\hline & & $\begin{array}{c}\text { Staphylococcus } \\
\text { aureus }\end{array}$ & Escherichia coli & $\begin{array}{c}\text { Pseudomonas } \\
\text { aeruginosa }\end{array}$ & $\begin{array}{c}\text { Klebsiella } \\
\text { pneumonia }\end{array}$ \\
\hline Ethylacetate & \multirow{4}{*}{ Aerial } & 1000 & 2000 & 1000 & 1000 \\
\hline Chloroform & & 500 & 2000 & 1000 & 1000 \\
\hline Ethanol & & 500 & 1000 & 2000 & 1000 \\
\hline Methanol & & 500 & 1000 & 500 & 1000 \\
\hline Ethylacetate & \multirow{4}{*}{ Roots } & 1000 & 2000 & 2000 & 1000 \\
\hline Chloroform & & 1000 & 2000 & 1000 & 1000 \\
\hline Ethanol & & 2000 & 4000 & 1000 & 1000 \\
\hline Methanol & & 500 & 2000 & 1000 & 500 \\
\hline
\end{tabular}

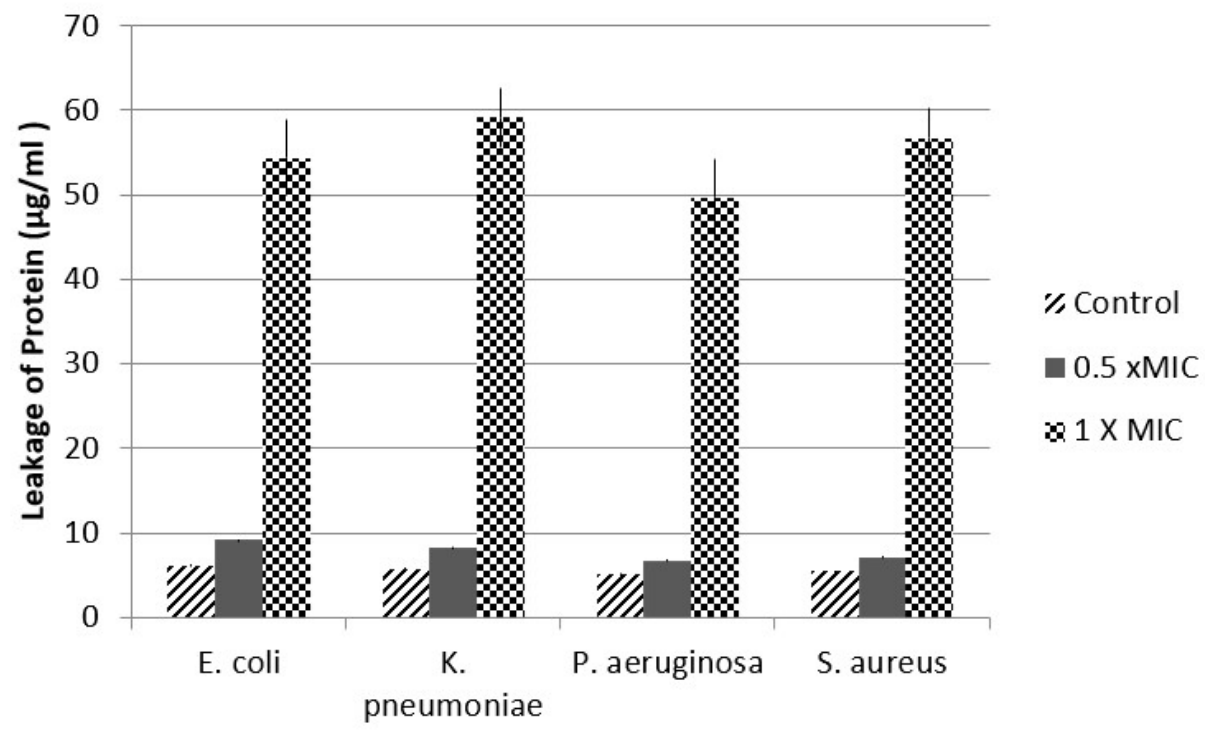

Figure 1. Effect of chloroform extract of Fagonia indica on membrane protein leakage. Bradford method was used to monitor the effect of various concentrations on leakage of protein. Values are presented as mean $+\mathrm{SE}$.

at a concentration of $1 \times$ MIC, resulted in significant $(P<$ 0.001 ) increase in protein leakage as compared to control cells or cells treated with plant extract at a concentration of $0.5 \times$ MIC respective to each bacteria (Figure 1 ). It was observed that maximum protein leakage was observed for K. pneumoniae ( $59.14 \mu \mathrm{g} \mathrm{mL} \mathrm{m}^{-1}$ ) followed by $S$. aureus $\left(56.7 \mu \mathrm{g} \mathrm{mL}^{-1}\right)$ as displayed in Figure 1.

Antiadhesion effect of sub-inhibitory concentrations of chloroform extracts of Fagonia was detected by using polystyrene surfaces of 96-wells microtiter plates. The results revealed that after 12 hours of incubation in the presence of chloroform extract, bacterial adhesion to the plastic surface was significantly reduced $\left({ }^{* * *} P\right.$ $<0.001$ ) when compared with control cells. This inhibition of adhesion was found to be $43.5-53.5 \%$ as depicted in Figure 2.
Static biofilm formation assay was employed to quantify biofilm formation in the presence and absence of subinhibitory concentrations of chloroform extract of Fagonia. The data indicated that biofilm forming capacity was increased in a time dependent manner among MDR bacteria and maximum capacity was observed for $P$. aeruginosa followed by K. pneumoniae (Figure 3). It was also observed that subinhibitory concentrations of chloroform extract of Fagonia significantly $(P<0.05)$ reduced the biofilm forming capacity of tested bacteria and percentage inhibition of biofilm formation was found to 30.33-71.84\% as compared with control cells. Moreover, it was also found that inhibition of biofilm formation was also time dependent as more inhibition was observed after 48 hours of incubation. Our data also revealed that after 48 hours of incubation, greater inhibition was observed for $S$. aureus (71.84\%) followed by K. pneumoniae (70.83\%)(Figure 3). 


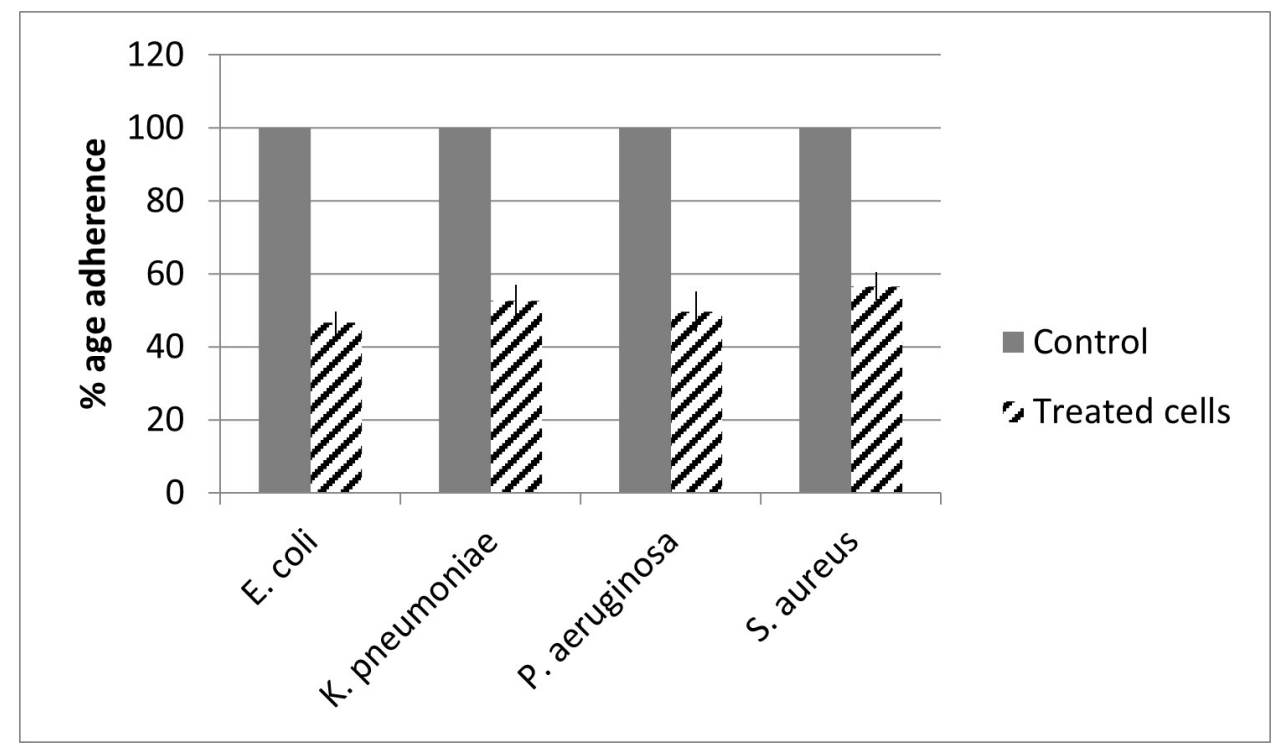

Figure 2. Effect of sub-inhibitory concentrations of chloroform extract of Fagonia indica on bacterial attachment to polystyrene surfaces. Cells grown in the absence of extract served as control. Values are presented as mean $+\mathrm{SE}$.

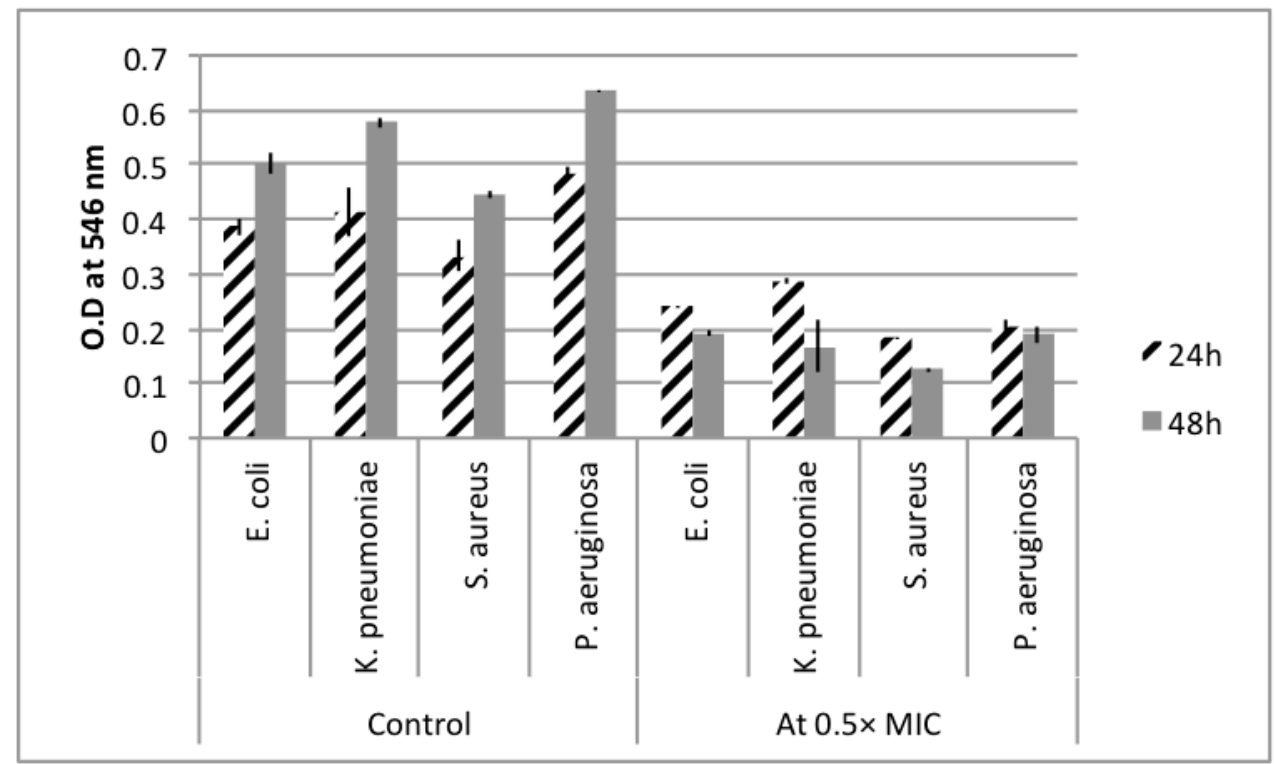

Figure 3. Effect of sub-inhibitory concentrations of chloroform extract of Fagonia indica on biofilm formation of MDR bacteria. Biofilms were quantified after 24 and 48 hours of incubation. Cells grown in the absence of extract served as control.

\section{Discussion}

For a long period of time, plants are considered as significant source of pharmacologically active ingredients. Significant results have been observed when plants and their active ingredients have been used as antimicrobial and antibiofilm agents (Höfling et al., 2010). The results of our study have revealed that Fagonia indica extracts can be potentially used as antibacterial and antibiofilm agents against MDR bacteria. There are numerous studies that explored the potential of naturally occurring bioactive compounds from plants as significant biofilm inhibitors probably due to their enhanced specificity and low toxicity (Koo and Jeon, 2009). Fagonia indica is one of the most important and popular members of genus Fagonia and a number of biologically active phytochemicals such as alkaloids, flavonoids, saponins, tannins and cardiac glycosides are present in this small tiny under shrub (Sharma et al., 2009; Anil et al., 2012). Agar well diffusion method has been extensively used to evaluate the antimicrobial activities of natural products such as plant extracts (Magaldi et al., 2004). It was observed that Fagonia extracts exhibited antibacterial activity in a dose dependent manner since increasing the concentrations 
of extracts increased the diameter of zone of inhibition. The largest zone of inhibition was observed against S. aureus using chloroform extract (concentration used was $1000 \mu \mathrm{g}$ $\mathrm{mL}^{-1}$ ) of plant made from aerial parts. It was also observed that some of the extracts (at the highest concentration tested) resulted in greater inhibitory zones against tested bacteria when compared with positive control (ampicillin). In a study by Ginovyan et al. (2017), antibacterial activity of Hypericum alpestre was tested and the results revealed that chloroform extract made from aerial parts resulted in inhibitory zone of $13 \mathrm{~mm}$ against $S$. aereus.

Agar well diffusion method is considered as preliminary test to check the antimicrobial activities of bioactive compounds, in order to further confirm the antimicrobial activities dilution methods are required. These methods are very appropriate to determine the MIC values since the concentration of tested drug can be estimated in agar or broth (Balouiri et al., 2016). Therefore, broth microdilution method was used to check the MIC and MBC of Fagonia extracts against MDR clinical isolates. According to the MIC and MBC results, Fagonia indica extracts particularly chloroform extract exhibited significant antibacterial potential against antibiotic resistant bacteria. Previous study by Rahman et al. (2017), also revealed the antimicrobial potential of various extracts of Fagonia indica. Another study by Sharma et al. (2009), also explored the antibacterial potential of ethanolic extract of Fagonia indica.

In order to exhibit antibacterial potential, bioactive compounds present in plant extracts may target many sites in bacteria. They can cause damage to cell wall, cell membrane, membrane proteins, depletion of proton motive force or may result in leakage of cellular content (Silva et al., 2019). Since, Fagonia indica extracts might cause damage to any of these targets, therefore, leakage of membrane protein was monitored after treatment of bacterial cells with different concentrations of chloroform extract of the plant. Our results indicated that chloroform extract of Fagonia indica cause a significant increase in the leakage of membrane protein possibly due to disintegration of cell membrane. While, in a study ethanolic extracts of Ficus benjamina leaves has been found to have antioxidant properties towards Pseudomonas aeruginosa and Escherichia coli (Ashraf et al., 2020).

For the therapeutic efficacy of antibiotics, concentration of drug administered should be greater than MIC value between consecutive doses. However, after certain time period different tissues contain concentration of drug, which is lower than the MIC value, and this value has been referred as sub-inhibitory concentrations. Although the sub-inhibitory concentrations of antimicrobial agents are ineffective to kill bacteria, yet have the capacity to alter various features such as chemical and physical nature of cellular surfaces and can also change the expression of different virulence factors (Wojnicz and Jankowski 2007; Pompilio et al., 2010). That's why sub-inhibitory concentrations of Fagonia indica used to check their effects on adhesion and biofilm formation of bacteria.

Adhesion to a living or non-living surface is considered to be the initial step in the formation of biofilm by microorganisms. Thus, if this crucial step will be targeted, virulence of bacteria will be decreased due to inhibition of their biofilm formation potential. One of our studies using chloroform extract of turmeric also revealed the antiadhesion potential of plants against antibiotic resistant bacteria such as E. coli, K. pneumoniae, E. cloacae and B. subtilis (Hayat et al., 2018). In the present study, we also observed significant inhibition of the attachment of bacterial cells to the plastic surfaces of 96 -wells microtiter plates after treatment of cells with Fagonia indica extract.

Biofilms present a considerable danger to the human health and are major contributors to various chronic infections. This association between biofilm formers and chronic infections is due to the increased potential of microbes to tolerate antibiotic treatments as well as immune response (Hathroubi et al., 2018). Therefore, to cope the antibiotic resistance exhibited by biofilm formers, novel biofilm inhibitors should be established. Our data revealed the efficient role of chloroform extract of Fagonia indica as biofilm inhibitor against MDR bacteria such as K. pneumoniae and E. coli. The results indicated that treatment of cells with plant extract inhibited $30.33-71.84 \%$ of biofilms as compared to the control cells. Numerous plant species are investigated for their biofilm inhibitory potential such as ginger, turmeric, cactus, Sticky snake weed etc (Kim and Park 2013; Hayat and Sabri 2016; Sánchez et al., 2016). However, our study explored the antibiofilm potential of Fagonia indica, since there was scarcity of data related to this plant.

Our study clearly suggested the efficient role of Fagonia indica extract as antiadhesion and antibiofilm agents against MDR bacteria. Biofilm formation is considered to be a major public health concerns, since more than $80 \%$ of microbial infections of human beings involve biofilm formers. Therefore, current study is significant, mentioning the role of Fagonia collected from Cholistan desertas biofilm inhibitors. However, in future there is a need to identify individual compounds from this plant responsible for this inhibition and also their molecular mechanism of action against antibiotic resistant bacteria.

\section{References}

AKHTER, R. and ARSHAD, M., 2006. Arid rangelands in the Cholistan desert(Pakistan). Science et Changements Planétaires/Sécheresse, vol. 17, no. 1, pp. 210-217.

ALI, S.S., KASOJU, N., LUTHRA, A., SINGH, A., SHARANABASAVA, H., SAHU, A. and BORA, U., 2008. Indian medicinal herbs as sources of antioxidants. Food Research International, vol. 41, no. 1, pp. 1-15. http://dx.doi.org/10.1016/j.foodres.2007.10.001.

ANIL, P., NIKHIL, B., MANOJ, G. and PRAKASH, N.B., 2012. Phytochemicals and biological activities of Fagonia indica. International Research Journal of Pharmacy, vol. 3, no. 6, pp. 56-59. http://dx.doi.org/10.1016/j.ijid.2003.03.002.

ARSHAD, M., ASHRAF, M. and ARIF, N., 2006. Morphological variability of Prosopis cineraria (L.) Druce, from the Cholistan desert, Pakistan. Genetic Resources and Crop Evolution, vol. 53, no. 8, pp. 1589-1596. http://dx.doi.org/10.1007/s10722-005-8563-5.

ASHRAF, A., ZAFAR, S., ASHRAF, M.Y., IJAZ, M.U., MUZAMMAL, S., ASAD, F., JABEEN, F. and SHAHID, M., 2020. Phytochemical composition and potent biological activities of Ficus benjamina var. Comosa leaves extract. Pakistan Journal of Botany, vol. 52, no. 2, pp. 531-535. http://dx.doi.org/10.30848/PJB2020-2(3).

BALOUIRI, M., SADIKI, M. and IBNSOUDA, S.K., 2016. Methods for in vitro evaluating antimicrobial activity: a review. Journal of Pharmaceutical Analysis, vol. 6, no. 2, pp. 71-79. http://dx.doi. org/10.1016/j.jpha.2015.11.005. PMid:29403965. 
CANLI, K., YETGIN, A., AKATA, I. and ALTUNER, E.M., 2016. In vitro antimicrobial activity of Angelica sylvestris roots. International Journal of Biological Sciences, vol. 1, no. 1, pp. 1-7. PMid:26722213.

DANIEL, M., 2016. Medicinal plants: chemistry and properties. Boca Raton: CRC Press. http://dx.doi.org/10.1201/b11003.

GINER, M.J., VEGARA, S., FUNES, L., MARTÍ, N., SAURA, D., MICOL, V. and VALERO, M., 2012. Antimicrobial activity of food-compatible plant extracts and chitosan against naturally occurring micro-organisms in tomato juice. Journal of the Science of Food and Agriculture, vol. 92, no. 9, pp. 1917-1923. http://dx.doi. org/10.1002/jsfa.5561. PMid:22246685.

GINOVYAN, M., PETROSYAN, M. and TRCHOUNIAN, A., 2017. Antimicrobial activity of some plant materials used in Armenian traditional medicine. BMC Complementary and Alternative Medicine, vol. 17, no. 1, pp. 50. http://dx.doi.org/10.1186/s12906017-1573-y. PMid:28095835.

HATHROUBI, S., SERVETAS, S.L., WINDHAM, I., MERRELL, D.S. and OTTEMANN, K.M., 2018. Helicobacter pylori biofilm formation and its potential role in pathogenesis. Microbiology and Molecular Biology Reviews, vol. 82, no. 2, pp. e00001-e00018. http://dx.doi. org/10.1128/MMBR.00001-18. PMid:29743338.

HAYAT, S. and SABRI, A.N., 2016. Screening for antibiofilm and antioxidant potential of turmeric (Curcuma longa) extracts. Pakistan Journal of Pharmaceutical Sciences, vol. 29, no. 4, pp. 1163-1170. PMid:27393429.

HAYAT, S., SABRI, A.N. and MCHUGH, T.D., 2018. Chloroform extract of turmeric inhibits biofilm formation, EPS production and motility in antibiotic resistant bacteria. The Journal of General and Applied Microbiology, vol. 63, no. 6, pp. 325-338. http:// dx.doi.org/10.2323/jgam.2017.01.004. PMid:29142162.

HÖFLING, J.F., ANIBAL, P.C., OBANDO-PEREDA, G.A., PEIXOTO, I.A., FURLETTI, V.F., FOGLIO, M.A. and GONÇALVES, R.B., 2010. Antimicrobial potential of some plant extracts against Candida species. Brazilian Journal of Biology = Revista Brasileira de Biologia, vol. 70, no. 4, pp. 1065-1068. http://dx.doi.org/10.1590/S151969842010000500022. PMid:21180915.

KIM, H.S. and PARK, H.D., 2013. Ginger extract inhibits biofilm formation by Pseudomonas aeruginosa PA14. PLoS One, vol. 8, no. 9, pp. e76106. http://dx.doi.org/10.1371/journal.pone.0076106. PMid:24086697.

KOO, H. and JEON, J.G., 2009. Naturally occurring molecules as alternative therapeutic agents against cariogenic biofilms. Advances in Dental Research, vol. 21, no. 1, pp. 63-68. http:// dx.doi.org/10.1177/0895937409335629. PMid:19717411.

KUMAR, N., KANT, R., SINAGA, M., YIMAME, B. and BEIACHEW, T., 2012. Preliminary phytochemical screening and in vitro antibacterial evaluation of the leaf and root extract of Azadirachto indica Plant. International Journal of Pharmaceutical Front, vol. 2, pp. 32-41.

MAGALDI, S., MATA-ESSAYAG, S., HARTUNG DE CAPRILES, C., PEREZ, C., COLELLA, M.T., OLAIZOLA, C. and ONTIVEROS, Y., 2004. Well diffusion for antifungal susceptibility testing. International Journal of Infectious Diseases, vol. 8, no. 1, pp. 39-45. http:// dx.doi.org/10.1016/j.jij.2003.03.002. PMid:14690779.

MAHDY, A., SHEHAB, N.G. and BAYOUMI, F.A., 2018. Protective effects of honey solution and Fagonia indica alcoholic extract against ethanol-induced gastric ulcer in rats. International Journal of Clinical Pharmacology \& Pharmacotherapy, vol. 3, no. 1, pp. 2-6. http://dx.doi.org/10.15344/2456-3501/2018/133.

MARWAT, S.K. and KHAN, I.U., 2012. Tracing the useful ethnophytomedicinal recipes of angiosperms used against jaundice and hepatitis in Indo-Pak subcontinent. World Applied Sciences Journal, vol. 18, no. 9, pp. 1243-1252.

MNAFGUI, K., HAMDEN, K., BEN SALAH, H., KCHAOU, M., NASRI, M., SLAMA, S., DERBALI, F., ALLOUCHE, N. and ELFEKI, A., 2012. Inhibitory activities of Zygophyllum album: a natural weight-lowering plant on key enzymes in high-fat diet-fed rats. Evidence-Based Complementary and Alternative Medicine, vol. 2012, pp. 620384. http://dx.doi.org/10.1155/2012/620384. PMid:23258993.

MOSTAFA, A.A., AL-ASKAR, A.A., ALMAARY, K.S., DAWOUD, T.M., SHOLKAMY, E.N. and BAKRI, M.M., 2018. Antimicrobial activity of some plant extracts against bacterial strains causing food poisoning diseases. Saudi Journal of Biological Sciences, vol. 25, no. 2, pp. 361-366. http://dx.doi.org/10.1016/j.sjbs.2017.02.004. PMid:29472791.

POLITOU, A. and TEMUSSI, P.A., 2015. Revisiting a dogma: the effect of volume exclusion in molecular crowding. Current Opinion in Structural Biology, vol. 30, pp. 1-6. http://dx.doi.org/10.1016/j. sbi.2014.10.005. PMid:25464122.

POMPILIO, A., CATAVITELLO, C., PICCIANI, C., CONFALONE, P., PICCOLOMINI, R., SAVINI, V., FISCARELLI, E., D'ANTONIO, D. and DI BONAVENTURA, G., 2010. Subinhibitory concentrations of moxifloxacin decrease adhesion and biofilm formation of Stenotrophomonas maltophilia from cystic fibrosis. Journal of Medical Microbiology, vol. 59, no. Pt 1, pp. 76-81. http://dx.doi. org/10.1099/jmm.0.011981-0. PMid:19762476.

PONTES, F.C., ABDALLA, V.C.P., IMATOMI, M., FUENTES, L.F.G. and GUALTIERI, S.C.J., 2019. Antifungal and antioxidant activities of mature leaves of Myrcia splendens (Sw.) DC. Brazilian Journal of Biology = Revista Brasileira de Biologia, vol. 79, no. 1, pp. 127-132. http://dx.doi.org/10.1590/1519-6984.179829. PMid:29742197.

RAHMAN, L., SHINWARI, Z.K., IQRAR, I., RAHMAN, L. and TANVEER, F., 2017. An assessment on the role of endophytic microbes in the therapeutic potential of Fagonia indica. Annals of Clinical Microbiology and Antimicrobials, vol. 16, no. 1, pp. 53-62. http:// dx.doi.org/10.1186/s12941-017-0228-7. PMid:28764775.

RAUT, J.S., SHINDE, R.B., CHAUHAN, N.M. and KARUPPAYIL, S.M., 2013. Terpenoids of plant origin inhibit morphogenesis, adhesion, and biofilm formation by Candida albicans. Biofouling, vol. 29, no. 1, pp. 87-96. http://dx.doi.org/10.1080/08927014.2012.74 9398. PMid:23216018.

SÁNCHEZ, E., RIVAS MORALES, C., CASTILLO, S., LEOS-RIVAS, C., GARCÍA-BECERRA, L. and ORTIZ MARTÍNEZ, D.M., 2016. Antibacterial and antibiofilm activity of methanolic plant extracts against nosocomial microorganisms. Evidence-Based Complementary and Alternative Medicine, vol. 2016, pp. 1572697. http://dx.doi.org/10.1155/2016/1572697. PMid:27429633.

SHARMA, S., JOSEPH, L., GEORGE, M. and GUPTA, V., 2009. Analgesic and anti-microbial activity of Fagonia indica. Pharmacologyonline, vol. 3, pp. 623-632.

SILVA, F.R.G., MATIAS, T.M.S., SOUZA, L.I.O., MATOS-ROCHA, T.J., FONSECA, S.A., MOUSINHO, K.C. and SANTOS, A.F., 2019. Phytochemical screening and in vitro antibacterial, antifungal, antioxidant and antitumor activities of the red propolis Alagoas. Brazilian Journal of Biology = Revista Brasileira de Biologia, vol. 15, no. 1, pp. 4-9. http://dx.doi.org/10.1590/1519-6984.182959.

STEPANOVIĆ, S., VUKOVIĆ, D., DAKIĆ, I., SAVIĆ, B. and ŠVABIĆVLAHOVIĆ, M., 2000. A modified microtiter-plate test for quantification of staphylococcal biofilm formation. Journal of Microbiological Methods, vol. 40, no. 2, pp. 175-179. http:// dx.doi.org/10.1016/S0167-7012(00)00122-6. PMid:10699673.

VAIBHAV, C., HIRAL, C.M. and DEVDHE, S., 2014. Selective in vitro antimicrobial properties of fagonia cretica linn crude extract. Journal of Advance Drug Delivery, vol. 1, no. 2, pp. 71-81.

WOJNICZ, D. and JANKOWSKI, S., 2007. Effects of subinhibitory concentrations of amikacin and ciprofloxacin on the hydrophobicity and adherence to epithelial cells of uropathogenic Escherichia coli strains. International Journal of Antimicrobial Agents, vol. 29, no. 6, pp. 700-704. http://dx.doi. org/10.1016/j.ijantimicag.2007.01.007. PMid:17382520. 